DOI: 10.24234/wisdom.v17i1.413

Yevheniia LEVCHENIUK,

Fedir VLASENKO,

Dmytro TOVMASH,

Ruslana ATASHKADEH,

Svetlana STEZHKO

\title{
ANTHROPOLOGICAL DIMENSION OF SMART CULTURE
}

\begin{abstract}
To carry out socio-philosophical conceptualization of the phenomenon of smart-culture as the newest sphere of human being, which emerges and develops in the era of informatization and technologization of society. The authors prove that the concept of "smart culture" is an evolutionary stage and unity of meanings of theoretical approaches to understanding the essence of modern society (information, virtual, global, etc.). It is proved that the condition and consequence of the emergence of a smart society is the development of a smart culture, which emerges as a unity of value models and technical and technological levels of development of civilization, which, in turn, forms a new subject - a smart person who tries to be realized as an individual through scientific advances, the latest information and communication technologies in a new living space. It is substantiated that the modern world is in a state of systemic, large-scale transformations, the result of which is in the emergence and development of new relations such as humanworld, human-society, human-city, human-community, etc.
\end{abstract}

Keywords: culture; smart culture; society; smart society; smart human.

Introduction

History of the development of anthropological teachings, especially in the XX century, provided a diverse range of concepts for understanding the essence of a man. For example, these are homo ludens (Huizinga, 2011), homo insciens (Ortega y Gasset, 1997) and so on. In the XXI century, modern philosophical anthropology has been replenished with new conceptual approaches to human understanding. In particular, such concepts as "posthuman" (Hayles, 2013; Fukuyama, 2004), “transhuman” (Epstein, 2009; Ku- tyrev, 2015) ${ }^{1}$, smart-human (Voronkova \& Kyvliuk, 2017) have appeared.

The opinion of well-known anthropologists, A. Helen and G. Plessner, is quite correct that man does not simply exist, but above all, he/she leads a life, thus creating various opportunities and ways of their realization. In other words, a person is what he/she does with themselves. In general, the development of modern philosophical anthropology is conditioned by two basic concepts. The first is the "concept of life", its founder can be considered F. Nietzsche, and the

1 See also: Zizek Slavoj. No Sex, Please, We're Post-Human! (http://www.lacan.com/nosex.htm). 
second - the "concept of existence", initiated by S. Kierkegaard. The first tradition states that man is, above all, a living being and is a part of nature. According to the conclusions of the second tradition, the man is a creature who, on the one hand, is doomed to "self" and on the other - to "catch" him/herself in being for granted. These concepts have defined the development of philosophical anthropology as a separate field of knowledge. But each of the representatives of philosophical anthropology justified their own vision of the essence of the human. In particular, M. Scheler (1988) argued that man occupies a special, exactly human place, separating it from the "natural" sphere. It represents the unity of the unreasonable impulse of life and mind, which it denotes by the term "spirit". That is, because of this, the man is distinguished from all over the animal world in that he is able to creatively relate to all processes and phenomena of reality. Continuing M. Scheler's line, G. Plessner argues that human essence cannot be reduced only to the body or only to the soul or consciousness. It is a psychophysically neutral being. The essence of man is the search for certainty through his/her comparison with other living beings. That is, a man is a creature that is able to organize his or her life through their activity, and they become who they are from the very beginning of their existence. Another theorist, A. Gehlen, substantiated the philosophy of human solely from the philosophy of nature. The man is seen as a creature lacking instincts and a being with nonspecialized sense organs. This is the reason for human activity. The result of this activity is the artificial world - culture. This is precisely the world in which man is able to survive. Culture, in turn, contains a gap between the aspiration and the action. It has the ability to form an "artificial" aspiration, as opposed to instinct. Summarizing his scientific research, A. Helen concludes that man is a social being, and therefore institutions replace instincts. They perform an adaptive function, helping to navigate the world, direct human activity in the appropriate direction, and so on. E. Rothhaker critically rethinks the legacy of his predecessors and argues that a person is a specific individual and always defined by an appropriate life (linguistic, cultural, ethnic environment), which has specific traditions, attitudes, values and more. The author uses the term "lifestyle" to refer to this.

Thus, it can be argued that modern person is no longer asserting him/herself, opposing him/ herself to the world of nature, and increasingly self-actualizing in the world of "artificial" (society), actively using the achievements of civilization (information and communication technologies, gadgets, social networks, etc.). This is, first of all, due to the high dynamicity of all processes of life of society and to the new levels of its existence and development, which is connected with the processes of intensive technology and informatization of the society as a whole, and of being an individual in particular.

Therefore, modern civilization progress can be characterized as a smart society, which has such predicates as rational, technical, innovative, the basis of which is the latest scientific and technological heritage of mankind. This leads to the emergence of the concepts of "smart-man", "smart-business", "smart-state", etc. The concept of "smart-society" also indicates the presence in the modern person of ample opportunities for direct participation in the development of the community, city, state due to the constant "inclusion" in all processes of life of society. As a consequence, a new dimension of the existence of society emerges - the smart culture, which is a symbiosis of traditions, value structures and 
newest achievements in order to ensure comfortable living conditions and development of a person. The latter simultaneously acts as the creator of the new world and an active consumer of the benefits of civilization.

Analysis of recent research works. That is why research of the smart society as a further evolutionary development of the information society is becoming increasingly relevant today. In particular, these are the works of such researchers as A. Andriienko, V. Voronkova, O. Kyvliuk, T. Romanenko, R. Andriukaitene (Voronkova, Romanenko, \& Andriukaitene, 2017; Voronkova \& Kyvliuk, 2017), S. Chukut, V. Dmytrenko (2016), A. Kusiak (2018), C. Wittenberg, B. Bauer, N. Stache (2020), M. A. Martinelli, J. A. Achcar, M. Hoffmann (2020). These approaches mainly focus on different vectors of smart-society development and forms of expression of "smart" (organizations, cities, manufacturing etc.).

The presented study focuses on the formation and development of smart culture as the basis and consequence of the formation of relevant social relations, mediated by the scientific, information and communicative achievements of civilization, without which the existence of modern person seems impossible.

The study involves the use of methods such as dialectical, hermeneutic, structural and functional, analysis, synthesis, which allow revealing the essence of smart-society, smart-culture from the standpoint of identifying new opportunities for human development. The synergistic approach allowed us to consider new scenarios of smart development in the context of the transformation of scientific, socio-cultural, economic foundations of human and society.

Goal. To carry out socio-philosophical conceptualization of the phenomenon of smart- culture as the newest sphere of human being, which emerges and develops in the era of informatization and technologicalization of society.

The major material to be introduced: the emergence of new conditions of human being, values, norms and patterns of behaviour in the process of development of a smart society determines the formation of the corresponding smart culture.

According to Ukrainian researchers V. Voronkova and O. Kyvliuk (2017) "smart culture is not an independent entity: it is an integral part of information culture, media culture, is based on them and develops them, contributing to human development as the creator of an innovative environment" (p. 92).

The development of smart culture is not possible without technology. They are at the same time the basis, the determining factor, which allows both to improve the existing and create new tools and opportunities for the development of a smart society. For example, projects such as smart-house, smart-cars, smart-appliances (TVs, telephones, watches, cleaning equipment) are becoming quite popular today. That is, the most comfortable arrangement of human space is made possible through the use of technical and technological achievements of civilization. This is realized through a kind of synthesis of culture and technology. Space (home, apartment) is seen as a kind of mechanism that can be controlled remotely by connecting to the Web, from cleaning and cooking to security, comfort, etc.

The new conditions of being, which resulted from the active introduction of modern technologies, also led to the emergence of the phenomenon of "smart-city". The latter is regarded as a three-tier model of the social world: 1) 
smart-city is characterized by the improvement of smart-technologies; 2) smart-city is a systemstructural, innovative world; 3) smart-city as socio-micro / socio-macro world of everyday life (Voronkova, Romanenko, \& Andriukaitene, 2017, p. 128).

Technologies of smart-city are actively developing all over the world, especially for metropolitan cities with well-developed Internet, which stimulates the emergence and development of social technologies. The smart city is primarily a city where public services become available through online mobile platforms, through mobile phones, with relevant pre-installed programs and applications, with heavy use of the Internet. Smart cities create the following conditions for the development of a "people-city" relationship in which an open government, accessible banks, active interaction with heads of cities, businesses, et are present.

Since 2014, a number of smart cities development initiatives have been developed in Ukraine. For example, the Smart-City project was implemented by the Dnipropetrovsk Regional Council. The basis of this project was the European model of European Smart Cities. This model encompasses six interconnected spheres of community life: smart governance, smart economics, smart mobility, smart people, smart environment, smart living (Voronkova \& Kyvliuk, 2017, p. 91).

It can be stated that in the metropolitan areas of Ukraine, these mandatory points are fulfilled to a certain extent. For example, "smart governance" involves the creation of portals of administrative services for both citizens and businesses and the formulation of urban policies with public participation. "Intelligent life" has components such as e-hospital, in particular, in Kyiv, almost every hospital has its IP-addresses, where it is possible to make an appointment with a doctor at a convenient time; there are also achievements in creating a single educational space; City security requires video surveillance in preschool, high schools, colleges, universities, public places, and more. The Smart People section provides for the creation and development of websites for community governance initiatives, web sites for distance learning and more. The Smart Environment section provides for appropriate public oversight of emissions and waste. This is a pressing issue for a number of industrialized cities in Ukraine. Smart Mobility is implemented through the creation of accessible WiFi zones both in educational establishments, transport and free access to information for the entire population of cities, towns and cities. And the last of Smart-City's proposed terms of development, "smart economy", involves the creation of urban socio-economic technology for obtaining, processing and storing information about objects with their spatial characteristics (Voronkova \& Kyvliuk, 2017, p. 92).

In this context, the modern researcher A. Andriienko notes that today the scientific discourse needs clarification of such concepts as "smart-city" and "e-city". "Within the study of different aspects of sustainable urban development, there are two main approaches to considering the term of the modern city. These are smart cities and e-cities. And while 5 years ago, these concepts could be clearly distinguished, there is now a complete transformation of approaches to understanding the essence of these concepts" (Andriienko, 2018, pp. 26-27).

Indeed, the rapid development of technology, the dissemination of information, and community involvement in the city's life requires appropriate theoretical generalizations in order for these factors to be effective in both urban and 
community development, personality, and people. "Smart city is a concept that is directly related to the automation of city life and its certain robotization" (Chukut \& Dmytrenko, 2016, p. 89).

So, today there is a radical change in the attitude of personality - society, personality - community, personality - city. Every citizen gets the opportunity to participate directly in the life and development of their own area, city, state, equipping the environmental world with the help of technologies that change social life in the direction of creating the most comfortable conditions of development. The basis of such transformations is the rational attitude of the person to reality, the awareness of their responsibility for the actions. As a result, there is a tendency in society to gentrification, reconstruction, renovation of old, abandoned buildings in unattractive parts of the city. For example, in the US in New York, the Bushwick Industrial Area has become a graffiti museum. In the United Kingdom, the Tate Modernist Gallery of Contemporary Art is operating on the site of the former Bankside Power Station. Ukrainian society also has significant gains in this area. In particular, the most progressive cities are Kyiv, Lviv, Kharkiv and others. In the capital, a striking example of gentrification is the National Cultural and Artistic and Museum Complex "Art Arsenal". In the XVIII century, there was a "gun yard" in which the artillery equipment was manufactured and repaired, and later this building was used as a weapons storage facility. By the beginning of the XXI century (in 2006), The Arsenal was used for industrial purposes, and in 2009 in the renovated building, with the support of the President of Ukraine V. Yushchenko, the first exhibition of items of the Ukrainian cultural heritage, called 'From Depths", was held. Currently, various exhibiti- ons, fashion shows, contemporary art demonstrations, lectures, training, etc., are regularly held in the Arsenal.

Another such example is the Expocenter of Ukraine National Complex, which did not function for a long time after the collapse of the USSR. Since the 2000s, various exhibitions have been regularly held here, and many films have been filmed, the concert hall is constantly functioning and so on. In the first building of the complex, there opens a permanent museum of Science, which will broadcast not only already known achievements but also the latest information and technical "breakthroughs" of domestic scientists. In August 2017, an electronic music concert was held at the Metrobus plant in Kyiv, where more than 50 performers performed, on 5 grand stages, where the most modern technical equipment was used. There are more and more such places and places that have received a "new life".

The development of a smart society transforms all spheres of human life, including manufacturing. Smart manufacturing is emerging and developing, the leaders of which are, for instance, Japan, the United States, and the EU. The proper functioning of smart manufacturing requires the proper development of technics and technology, with the ongoing involvement of the Internet, as smart manufacturing becomes possible through close international cooperation. Smart manufacturing involves the use of wireless technology, a variety of sensors, which can accelerate data analysis. "As manufacturing is becoming digital and virtual, much of the creative and decision-making activities will take place in the digital space. While at some level, the digital space may be highly transparent, the physical manufacturing assets with their know-how will be protected. This digital-physical separation will 
allow for shared use of resources across businesses, including the ones that compete" (Kusiak, 2018, p. 511).

The introduction of smart manufacturing is changing the relation of "human-machine", "human-technique", which determines the appearance of virtual engineering, "virtual twins", and supplemented reality (Wittenberg, Bauer, \& Stache, 2020, p. 161). Branches such as computational neuroscience, virtual worlds and society, cognitive science and systems are emerging. Intelligent governance is emerging and evolving, prompting the emergence of a new paradigm of learning, namely, the use of new smart technologies in the educational process, which causes the ethics of machine management of knowledge (Wittenberg, Bauer, \& Stache, 2020, p. 163).

It should be noted that such a sphere of culture as education today is also undergoing significant changes. The use of information and communication technologies in the educational process makes education accessible, effective enough, actively involving the applicant. New forms of educational services are emerging "distance learning", "e-learning", etc. According to scientists, the active use of electronic and communication technologies in education will contribute to the formation of an active, responsible and independent personality. "It forms smart citizens who are highly educated, as they use modern technologies, act collectively and take part in government". "At the heart of smart education is the formation of the subject's smart competence as an integral part of information competence: knowledge about the smart environment and how to interact with it; ability to search and use smart-resources, smart-technologies. Interaction in a smart environment should be carried out in the context of interaction with the media environment and cyberspace, which involves the implementation of multilingual modal logic. The formation and development of smart education involve the formation of a culture - smart interaction in the smart environment, smart security, computer and information ethics. In the context of increasing the volume of information flows, shortening the life cycle of knowledge, increasing requirements for professional characteristics of the individual, the rapid nature of social change, etc. education loses its basic one-dimensional nature and acquires the properties of a consistent, systematic, continuous process" (Voronkova \& Kyvliuk, 2017, pp. 8895).

So really, all higher education institutions around the world have their own web pages, which contain all kinds of information. Ukrainian universities are no exception, and the websites of Ukrainian universities offer information about the institution's history, administration, reports, events; Every university structural unit has its sites, for example, institutes, faculties, departments; information is also available and constantly updated for students: schedules, session schedules, etc., as well as for students with a schedule of meetings with the administration, teaching staff of the faculty they wish to attend. For example, the site of the Faculty of Philosophy of Taras Shevchenko National University of Kyiv.

Researchers of transformation processes in the educational field believe that today, the university space network has expanded significantly, despite the fact that it is controlled in some way but is still open to all kinds of events (Hanke, 2016, p. 155).

That is, innovative education is now a determining factor of the development of the individual, the steady progress of society, its main resource. 


\section{Conclusion}

Considering all of the above, it must be stated that the achievements of mankind in the technosphere have created new effective conditions for the development of modern society and man. The latter rationally and usefully arranges its space, various devices make its life comfortable, convenient and allow to unload the person that gives a chance to it as much as possible useful and pleasant to spend time. At the same time, it creates appropriate challenges to which the individual is often unprepared.

First, modern man is increasingly forced to self-actualize in the "artificial" virtual world, actively using information and communication technologies, gadgets, social networks and more. Thus, human socialization in virtual reality is carried out in the context of the interaction of two processes: the assimilation of individual norms and patterns of behaviour which people perceive in the primary social reality and the internalization of norms, values, settings of virtual space. At the same time, a person who returns to the primary social reality faces the problem of finding his or her own identity. And the urgent task of society is to optimize the relevant identification processes.

Secondly, smart-culture is a set of comfortable conditions of human existence and development created by modern society with the help of the latest technologies in symbiosis with scientific achievements and valuable achievements of civilization. Under such conditions, the effective development of personality is possible in resolving socio-cultural and ideological contradictions in the presence of sufficiently developed material and spiritual prerequisites. The main guidelines for human development are the values of individuality, continuing education, entrepreneur- ship, which must be cultivated and maintained by the entire system of social institutions.

Third, the development of smart culture is not possible without technology. At the same time, they are the basis, a powerful factor that allows both to improve existing and create new tools, opportunities for the development of smart-society. This is due, first of all, to the high dynamics of all life processes of society, the emergence of qualitatively new levels of its existence and development, which is associated with the processes of intensive technology and informatization. In this regard, such personality characteristics are updated as professionalism (in the direction of using modern technologies); spirituality as the predominance of spiritual and moral, intellectual qualities (values) over material ones; social responsibility as a measure of compliance of actions of social subjects with mutual requirements, current legal and other norms and common interests; ability to creatively build and implement their own life project through direct participation in the life and development of their district, city, state.

Fourth, rapid socio-cultural change poses challenges that neither the education system, nor the upbringing system, nor all past life experience has prepared for. It can function successfully only with the appropriate personal qualities and behavioural skills, among which are: creativity, activity, readiness for a large number of options, responsibility, professionalism, competence, competitiveness.

\section{References}

Andriienko, A. O. (2018). The Concept of "Smart City": Clarification of Key Concepts in the Context of Ensuring the Development of a Large Municipa- 
lity. Public Administration Aspects, 6(8), 24-34. https://doi.org/10.15421/151843.

Chukut, S. A., \& Dmytrenko. V. I. (2016). Smart City or E-City: Modern Approaches to Understanding E-Government Implementation at the Local Level. Investment: Practice and Experience, 13, 8993.

Epstein, M. N. (2009). Tvorcheskoe ischeznovenie cheloveka. Vvedenie v gumanologi$y u$ (The Creative Disappearance of the Human Being: An Introduction info Humanology, in Russin). Russian Journal of Philosophical Sciences, 2, 91105.

Fukuyama, F. (2004). Nashe postchelovecheskoe budushchee: Posledstviya biotekhnologicheskoi revolyutsii (Our Posthuman Future: Comsequences of the Biotechnology Revolution, in Russian). (M. B. Levin, Trans.). Moscow: OAO "LYUKS".

Hanke, B. (2016). The Network University in Transition. In R. Foshay (Ed.), The Digital Nexus: Identity, Agency, and Political Engagement (pp. 151-183). AU Press. https://doi.org/10.15215/aupress/9781771991292.01.

Hayles, N. K. (1999). How We Became Posthuman: Virtual Bodies in Cybernetics, Literature and Informatics. Chicago: The University of Chicago Press.

Huizinga, J. (2011). Chelovek igraiushchi (Homo Ludens, in Russian). (D. V. Silvestrova, Trans). Saint Petersburg: Ivan Limbakh Publication.

Kusiak, A. (2018). Smart Manufacturing. International Journal of Production Re- search, 56(1-2), 508-517. https://doi.org/10.1080/00207543.2017.1351644.

Kutyrev, V. A. (2015). Poslednee tselovanie. Chelovek kak traditsiya (The Last Kissing: The Man as Tradition, in Russian). From the Series "The Tought's Bodies". Saint Petersburg: Aleteya.

Martinelli, M. A., Achcar, J. A., \& Hoffmann, M. (2020). Cidades inteligentes e humanas: percepção local e aderência ao movimento que humaniza projetos de smart cities. Revista Tecnologia e Sociedade, 16(39), 147-164. doi:10.3895/rts.v16n39.9130.

Ortega y Gasset, J. (1997). Izbrannye trudy (Selected Writings, in Russian). Moscow: Ves' mir.

Scheler M. (1988). Polozhenie cheloveka v kosmose (The Human Place in the Cosmos, in Russian). In The Problem of Man in Western Philosophy (pp. 3195). Moscow: Progress.

Voronkova V., Romanenko T. \& Andriukaitene R. (2017). G'eneza vid informacijnogo suspil'stva do "smart-suspil'stva" $v$ konteksti istorychnoi' evoljucii' suchasnogo svitu: teoretyko-konceptual'nyj kontekst (Genesis from the Information Society to the "Smart Society" in the Context of the Historical Evolution of the Modern World: Theoretical and Conceptual Context, in Ukrainian) Collection of Scientific Works "Gilea: Scientific Bulletin”, 116(1), 128-133.

Voronkova, V., \& Kyvliuk, O. (2017). Ljudyna u osvitn'omu prostori smart-suspil'tsva (Individual at the Educational Space of Smart-Society, in Ukraine). Interdisciplinary Studies of Complex Systems: 
Collection of Scientific Works, 10-11, 88-95.

Wittenberg, C., Bauer, B., \& Stache, N. (2020). A Smart Factory in a Laboratory Size for Developing and Testing Innovative
Human-Machine Interaction Concepts. In (T. Ahram \& Ch. Falcão, Eds.), Advances in Intelligent Systems and Computing (pp. 160-166). Washington D.C, USA. 